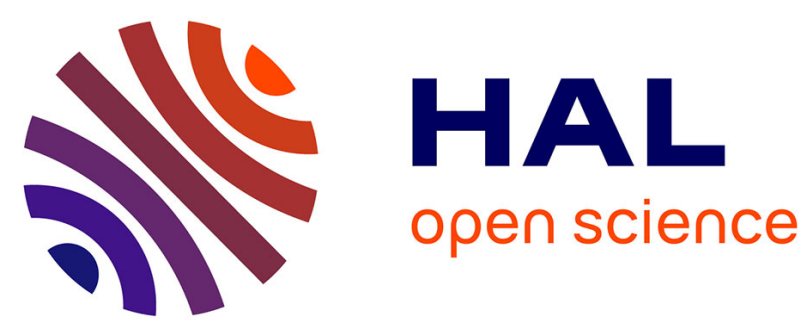

\title{
Neotectonics and current hydrologically-induced karst deformation. Case study of the Plateau de Carlern (Alpes-Maritimes, France)
}

Eric Gilli, Frédérick Boudin, Laurent Longuevergne, Nicolas Florsch, J.J. Walsch, Alain Gomez, Jacques Depeyre, J.C. Marie

\section{To cite this version:}

Eric Gilli, Frédérick Boudin, Laurent Longuevergne, Nicolas Florsch, J.J. Walsch, et al.. Neotectonics and current hydrologically-induced karst deformation. Case study of the Plateau de Carlern (Alpes-Maritimes, France). Geodinamica Acta, 2010, 23 (1-3), pp.49-64. 10.3166/ga.23.49-64 . hal00708116

\section{HAL Id: hal-00708116 https://hal.science/hal-00708116}

Submitted on 14 Jun 2012

HAL is a multi-disciplinary open access archive for the deposit and dissemination of scientific research documents, whether they are published or not. The documents may come from teaching and research institutions in France or abroad, or from public or private research centers.
L'archive ouverte pluridisciplinaire HAL, est destinée au dépôt et à la diffusion de documents scientifiques de niveau recherche, publiés ou non, émanant des établissements d'enseignement et de recherche français ou étrangers, des laboratoires publics ou privés. 


\title{
Neotectonics and current hydrologically-induced karst deformation. Case study of the Plateau de Calern (Alpes-Maritimes, France)
}

${ }^{\mathrm{a}}$ Eric GILLI, ${ }^{\mathrm{b}}$ Fréderic BOUDIN, ${ }^{\mathrm{c}}$ Laurent LONGUEVERGNE, ${ }^{\mathrm{d}}$ Nicolas FLORSCH, ${ }^{\mathrm{e}}$ Jean-Jacques WALCH, ${ }^{\mathrm{e}}$ Alain GOMEZ, ${ }^{\mathrm{e}}$ Jacques DEPEYRE and ${ }^{\mathrm{f}}$ Jean-Claude MARIE.

\author{
a * Geography dept. University of Paris 8 \& UMR Espace 6012, Nice, France (e.gilli@wanadoo.fr) \\ b UMR 5243, Géosciences Montpellier, University of Montpellier 2, France (frederic.boudin@gm.univ- \\ montp2.fr) \\ c Department of Geological Sciences and Bureau of Economic Geology, Jackson School of Geosciences, The \\ University of Texas, Austin, TX, USA (Laurent.longuevergne@beg.utexas.edu) \\ ${ }^{\mathrm{d}}$ UPMC / IRD UMI No. 209 Paris, France and Dept. of Math. and Applied Math. University of Cape Town, \\ South Africa, (nflorsch@gmail.com) \\ ${ }^{\text {e }}$ UMR 6203, GEMINI, OCA, Nice / Grasse, France \\ ${ }^{\mathrm{f}}$ CAF Caving Club Martel Nice, France
}

\begin{abstract}
The astronomical and geodetic observatory OCA, located on the karst plateau of Calern (Caussols, France), has been monitoring earth deformation for several years. Two long baseline tiltmeters have been installed in a shaft in 2007, along with classical hydrogeological monitoring tools in order to investigate the relationship between current karst deformation and hydrology. Dye tests have shown that the plateau is drained towards the East, to the spring of Bramafam, except for its Western third. Karst tilting, as recorded by the tiltmeters, is linked to rainfall events. These instruments bring additional information to characterize different reservoirs: the deep karst aquifer of Bramafan with high amplitude oscillations of its water table, up to $100 \mathrm{~m}$, the perched aquifer of Moustiques shaft whose response is attenuated, and several slope aquifers with reduced oscillations (Fontaniers, Castel Bon Pré).

Tilt deformation reaches $8 \mu \mathrm{rad}$ with a definite orientation between $\mathrm{N} 90^{\circ} \mathrm{E}$ and $\mathrm{N} 100^{\circ} \mathrm{E}$. The best correlation between hydrology and tilts is observed for the deep aquifers. If the first autumn rainfall is ineffective on tilt, it recharges the epikarst and refills the reserves. The winter rains cause the water to flush towards the eastern deep aquifer and provokes a quick tilting of the plateau. Finally, the long term variations in tilt and water table show a very good correlation
\end{abstract}

The relationship between current hydrological deformations and tectonics is also analyzed; broken and shifted speleothems in the shafts indicate a general shift of the plateau towards the south.

Keywords : Karst, geodesy, tectonics, tilt, hydrology 


\section{INTRODUCTION AND HISTORICAL RESEARCH}

The Calern plateau is located $27 \mathrm{~km}$ East of Nice in the "Arc de Castellane" which is part of the subalpine area. It is a limestone area characterized by the presence of many thrusting units resulting from compression phases in the development of the Alps. The Calern plateau overthrusts another limestone unit : the Caussols plateau. The astronomical observatory of Calern (OCA) is located on the karstic plateau where seasonal variations of gravity are observed since 1998 [1]. They are accompanied by changes in elevation measured with GPS and laser ranging [2]. In addition, measurements taken between 1973 and 1977 on the site of the Observatory of Calern had shown variations of tilt of the plateau up to 10 seconds per year and an hydrogeological cause was then suggested [3].

Various directions have been explored to understand these seasonal deformations, which have led to interest in underground signs, in the endokarst. This sector is indeed a well-developed karst topography with many cavities whose network of caves (Baoudillouns-MoustiqueCalernaum, $500 \mathrm{~m}$ deep, spanning nearly $20 \mathrm{~km}$ ) is a window on deep underground karst. Several hydrogeological studies have shown that Calern and Caussols units are drained eastward, towards the Loup valley where powerful springs are present.

Observed gravity variations in OCA may be linked to water mass variations within the karstic system of Calern. Hydrological data on the karstic water table [4] and rainfall data from the weather station of Calern have been studied from September 1997 to May 1999, but no relationship was observed between gravity variations and the hydrology [5]. However this study remained very simple and needed to be clarified. Another hypothesis has been raised by Nicolas and al [6] ; they linked gravity variations observed in OCA to the continental-scale deformation induced by the water mass variations over Europe as a whole.

A tectonic origin was also considered, as many recent signs of deformation were observed in the caves of Southeastern France [7] [8] and especially in the shaft of Aven Abel (St-Vallier de Thiey) located $12 \mathrm{~km}$ south of the study area [9]. Indeed, given the geometry of the limestone plateau that is tilted between $30^{\circ}$ and $45^{\circ}$, a movement towards the south could provoke a slight uplift of the plateau, which could also explain the observed geodetic variations. Finally GPS measurements have confirmed a North-South tightening [10]. Many signs of neotectonics have indeed been observed in the Calernaum shaft

\section{THE CALERNAUM SHAFT}

\subsection{Description}

In the Calernaum shaft, a series of vertical pits cross the Jurassic limestone of Calern, down to the thrusting plane, $200 \mathrm{~m}$ below the surface (Fig 1). A level of marls can be reached. It belongs to the tectonic unit of Caussols (Fig 2). The Lias and the Trias are absent. The Bajocian is in an abnormal position, lying on the Cenomanian marls but there is often a sharp contact between the underside of a bed of Bajocian limestone and the marls, giving the illusion of a normal contact. The thrusting fault is not a single plane, but includes a series of parallel planes, like a card-game (Fig 3). In many places, limestone beds are anchored in the underlying marls, and the rupture plane is located a few meters above the normal contact, causing the presence of slicken-slides. 


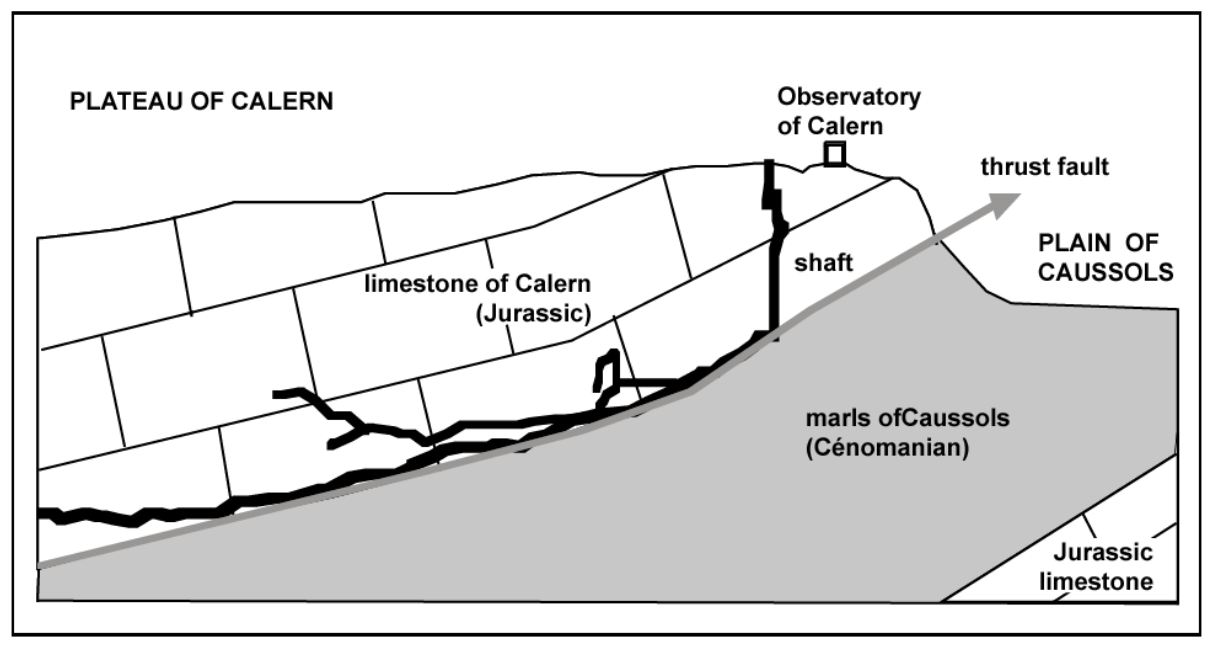

Figure 1: Cross section of the shaft of Calernaum

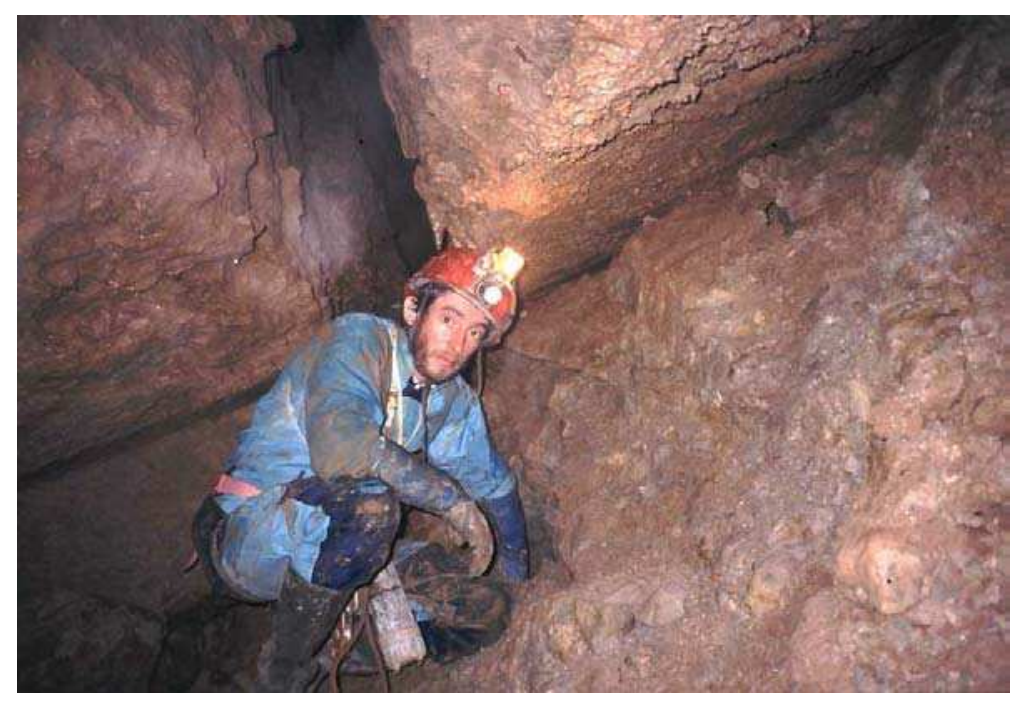

Figure 2: Basis of the thrusting unit of Calern. The caver is on Caussols Cenomanian marls, above him is the Jurassic limestone that belongs to the Calern unit

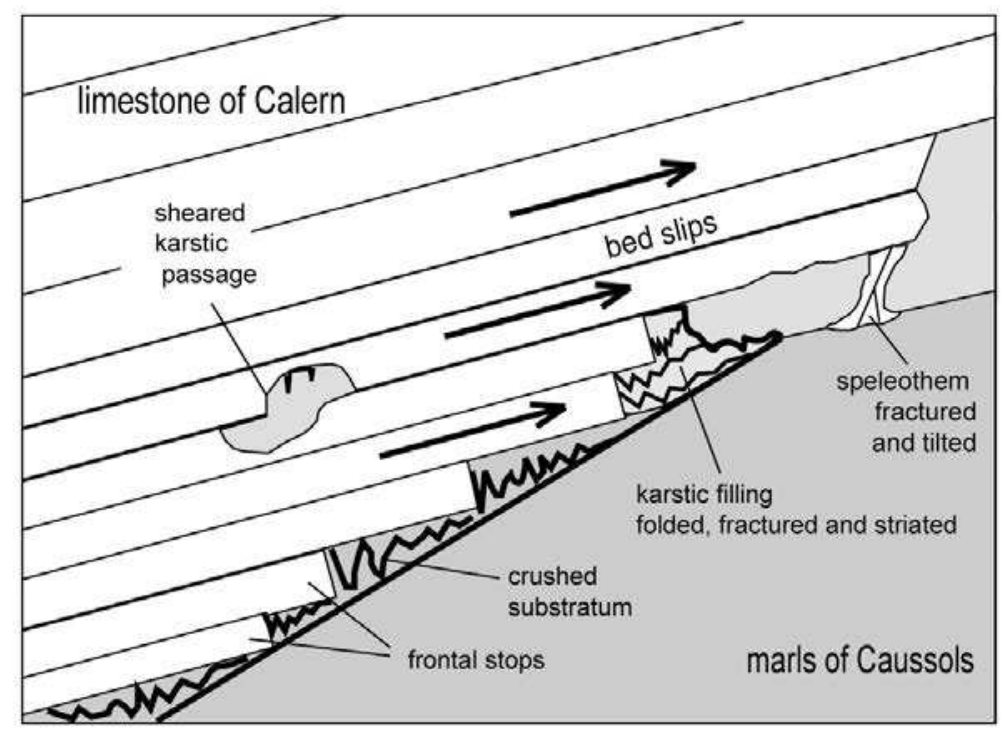

Figure 3: Diagram of sliding limestone beds above the overthrust plane, and associated signs of deformation. 


\subsection{Signs of neotectonics}

In places where the limestone beds are anchored in the marls, it is frequent to observe karstic sediment, folded or crushed speleothems and clays, squeezed between the marls and the limestone. These signs reflect a north-south compression. At the contact between marls and limestone, the striations in the Bajocian limestone beds are oriented NS. The clay placed immediately below the contact also shows striations (Fig 4). In places where stalactites and stalagmites are present, breaks indicating a movement of the Calern unit towards South may be observed (Fig 5-6). These endokarstic sediments filling the cave are younger than the karstic network. Therefore, the movement that caused the damage is supposed to be recent as it is difficult to imagine the existence of the karstic system before the thrusting of the different tectonic units.

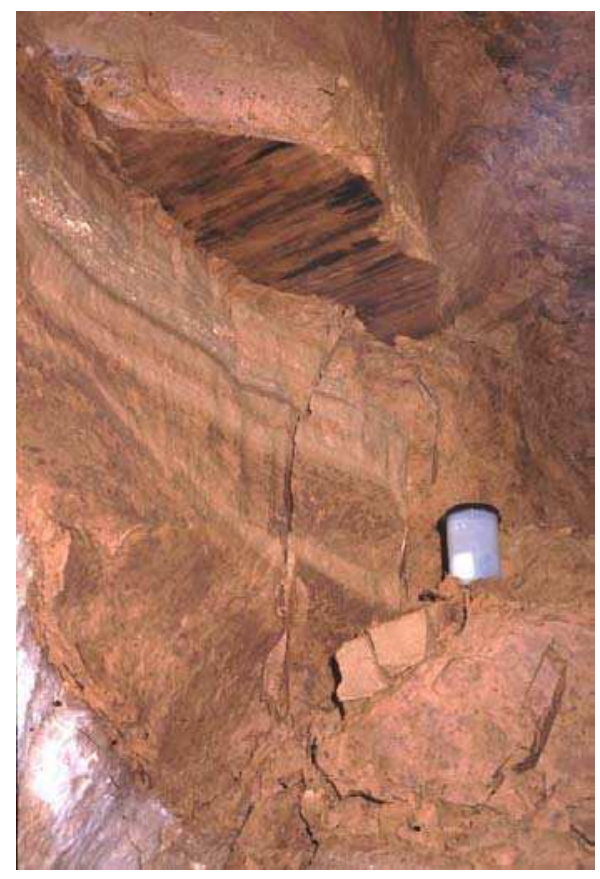

Figure 4: Striation in the karst filling below the thrust plane

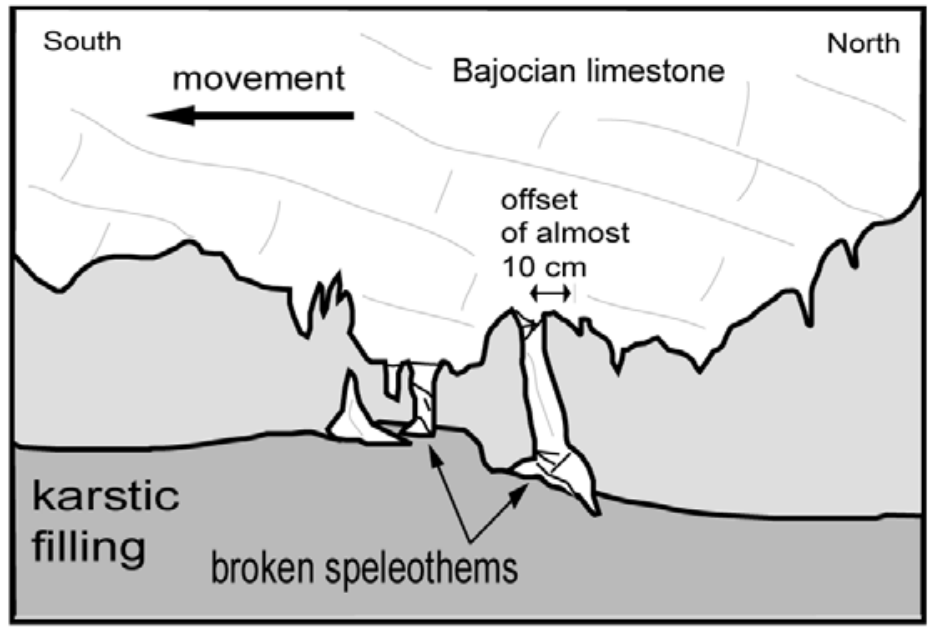

Figure 5: Speleothems broken by the movement of the thrust fault. 


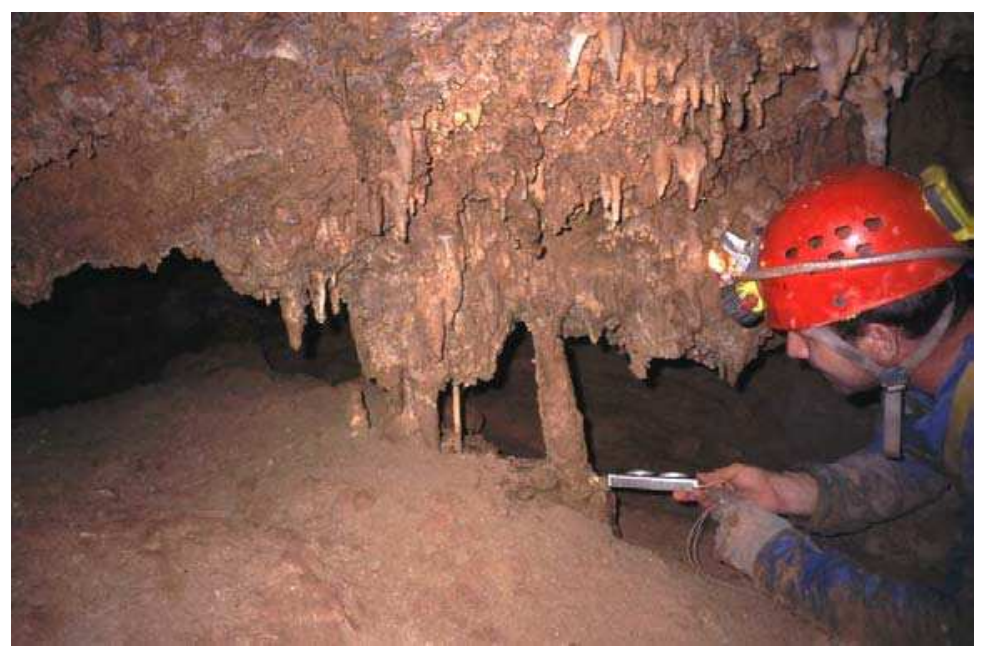

Figure 6: Speleothem displaced by the thrust plane movement.

To characterize the movement, a displacement sensor was installed into the shaft of Calernaum, at a depth of $250 \mathrm{~m}$, between two limestone beds, where slicken slides revealed a N-S orientation (Fig 7). This location, a few meters above the main thrusting plane is better than a contact limestone/marls, where it would have been technically difficult to anchor the sensor in the marls.

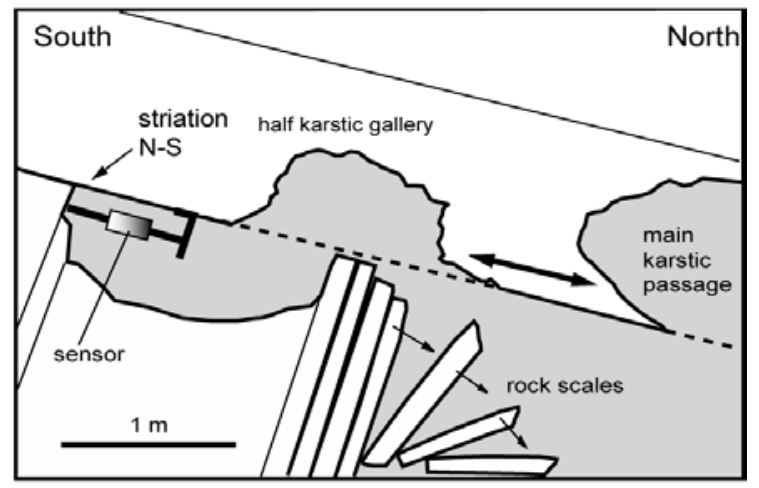

Figure 7: Sketch of the structural environment of the displacement gauge installed in the Calernaüm shaft.

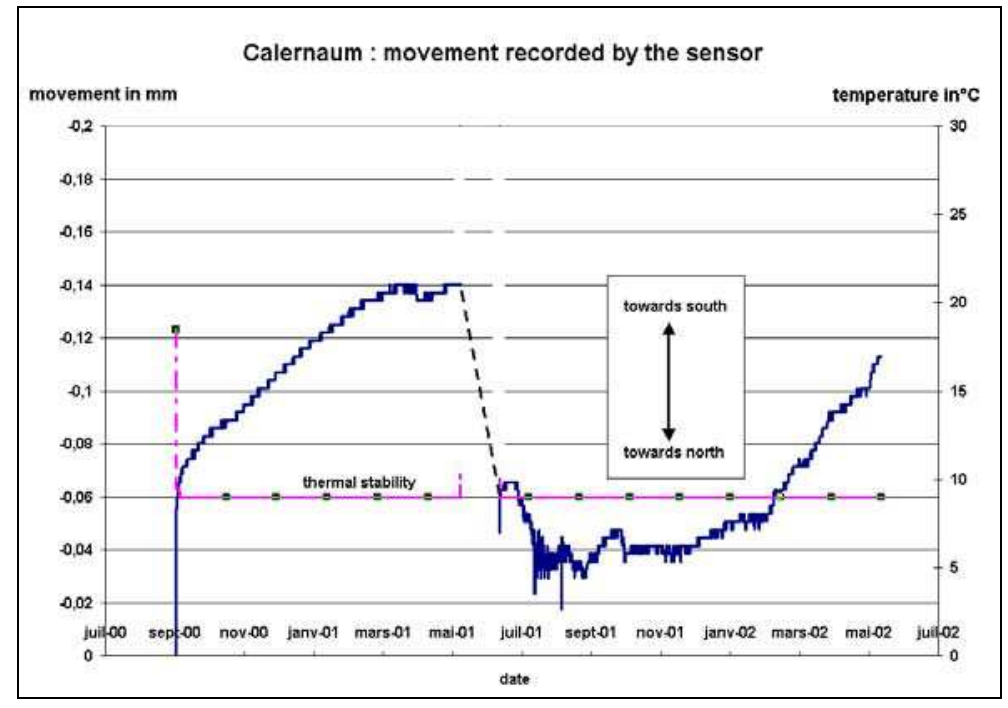

Figure 8: Movement recorded by the gauge installed on the thrust fault plane in the Calern overthrusting unit from September 2000 to May 2002. 
The data logged over 20 months indicates that the movement alternates, south to north then north to south, with a maximum amplitude of $0.12 \mathrm{~mm}$ (Fig 8). The data was compared with the gravity and altitudinal data acquired by the OCA (Fig 9). A good correlation with changes in altitude (GPS and laser) suggests that the movement measured in the cave is a slight component of the general movement of the plateau. When the plateau rises up, a compression affects the limestone beds. When the plateau moves down, a distension appears.

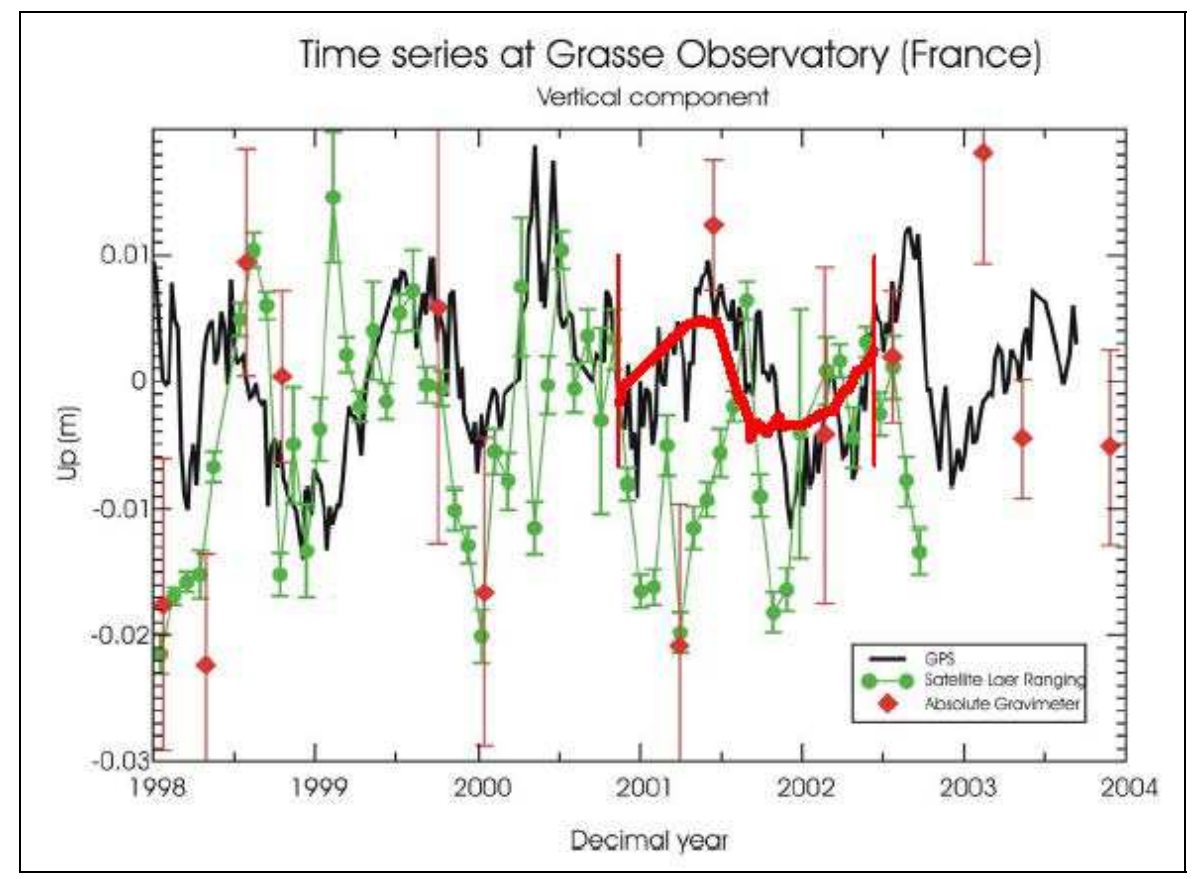

Figure 9: Comparison between the gravimetric changes (Nicolas et al, 2003) and the movement of the thrust plane observed in the shaft of Calernaum.

The cyclic movement makes the tectonic hypothesis doubtful, unless we admit a mechanism type action-reaction, or alternating phases of compression and relaxation of constraints. The fractures that affect the speleothems are probably old and dating is in progress to confirm that hypothesis. An hydrological cause remains the most likely, which is developed in the paper.

\section{HYDROGEOLOGY OF CALERN}

The general pattern is a set of two limestone units Calern / Caussols, separated by a thick impervious level of Cenomanian marls. The impluvium of Calern-Caussols feeds a deep aquifer that develops in the Caussols unit, in a limestone gutter-shaped unit, oriented eastwest. It is drained eastward by the Bramafan spring, in the Loup valley. The module of Bramafan is $416 \mathrm{~L} / \mathrm{s}$ (data from 1982 and then from 1987 to 1991), floods and other potential outlets are however not measured (leakages in Bramafan, Laquet spring, Revest cave, ...). The total average water throughput is higher, estimated around $600 \mathrm{~L} / \mathrm{s}$.

The detailed spatial organization of the aquifers is poorly known because of large uncertainties that remain about the deep structure of the limestone units. Nevertheless, two water bodies were identified in the studied area (Fig 10) : 
- $\quad$ a perched aquifer in Calern unit, probably of low volume, located at a depth of 200 m. Its aquiclude is the impervious level of Cenomanian marls or the Keuper clays,

- the previously described main aquifer, about $700 \mathrm{~m}$ deep, in the limestone unit of Caussols.

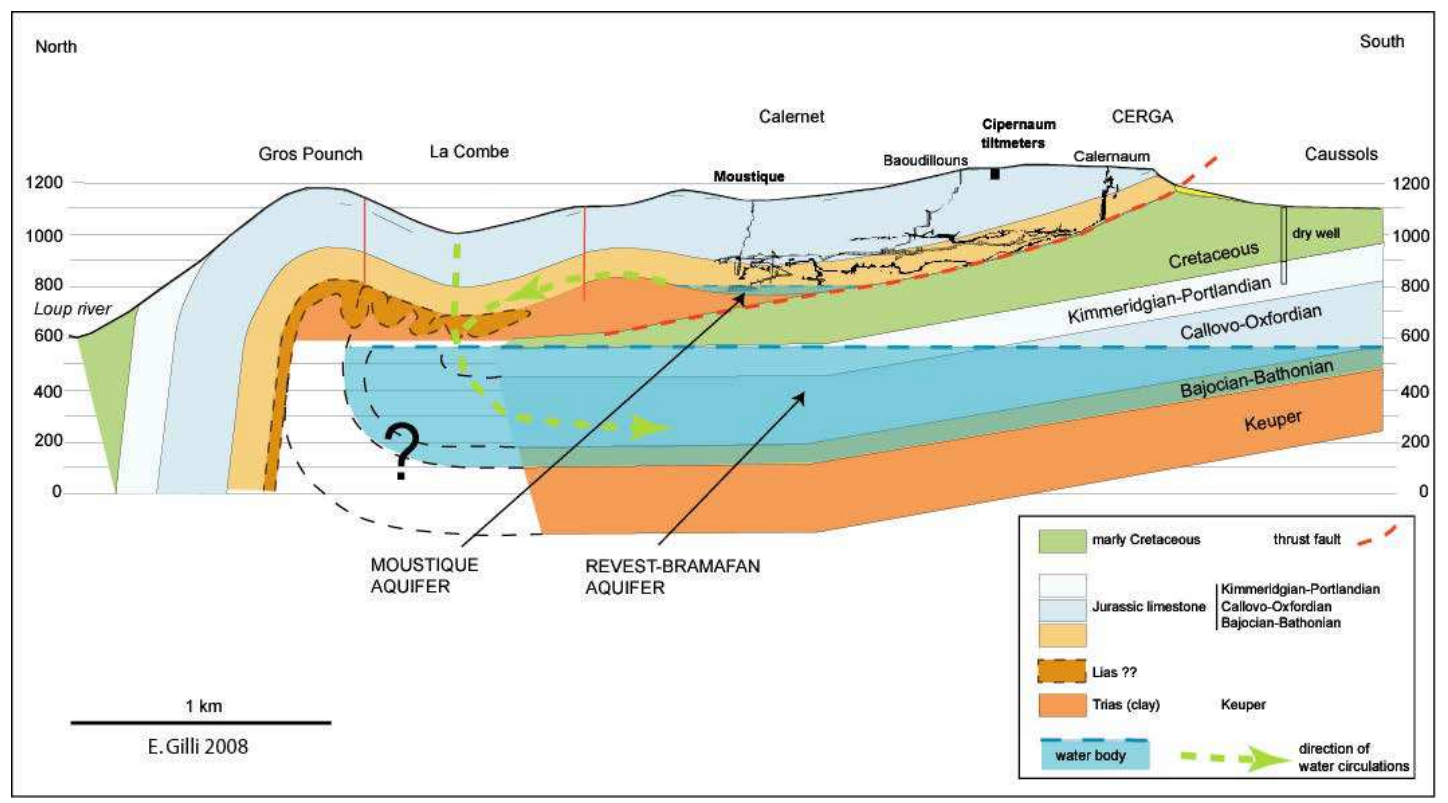

Figure 10: North-South geological section of Calern Plateau.

Large fluctuations in water table have been observed in these two layers, resulting in significant flooding at the outlet. Furthermore the important fracturing and decompression of the surface limestone favor the presence of an epikarst in which a discontinuous surface aquifer may be present.

The hydrogeology of this area has been specified by several dye tests summarized on figure 11. The last one, directed in 2008 by the General council of Alpes-Maritimes and the Departmental committee of cavers, helped to remove uncertainty about the northern and western areas of Calern plateau. It showed a rapid link between the sinkhole of Haute Combe and the Bramafan spring, with a speed of $170 \mathrm{~m} / \mathrm{h}$. It also showed that the area of La Pinée (West of Calern) is not included in the water basin.

The basin area is now estimated at $32 \mathrm{~km}^{2}$. The deduced infiltration module is about $20 \mathrm{~L} / \mathrm{s} / \mathrm{km}^{2}$, which is consistent with rainfall measured in this area and evapotranspiration. Average rainfall for the period 1955-1980 is $1200 \mathrm{~mm} / \mathrm{yr}$ and evapotranspiration is around $600 \mathrm{~mm} / \mathrm{yr}(50 \%$ of rainfall). In the absence of effective rainfall, runoff is about $600 \mathrm{~mm} /$ year which corresponds to a calculated module of $19 \mathrm{~L} / \mathrm{s} / \mathrm{km}^{2}$

The karstification of the area is important and the aquifer systems react quickly and strongly to rain. Very fast underground water circulations were measured in this area $(400 \mathrm{~m} / \mathrm{h}$ between the sinkhole of Caussols and Bramafan spring).

During flood period various springs are visible on the right bank of the Loup river, below and above the Bramafan spring and exceptionally the Revest cave resurges $240 \mathrm{~m}$ above Bramafan. 


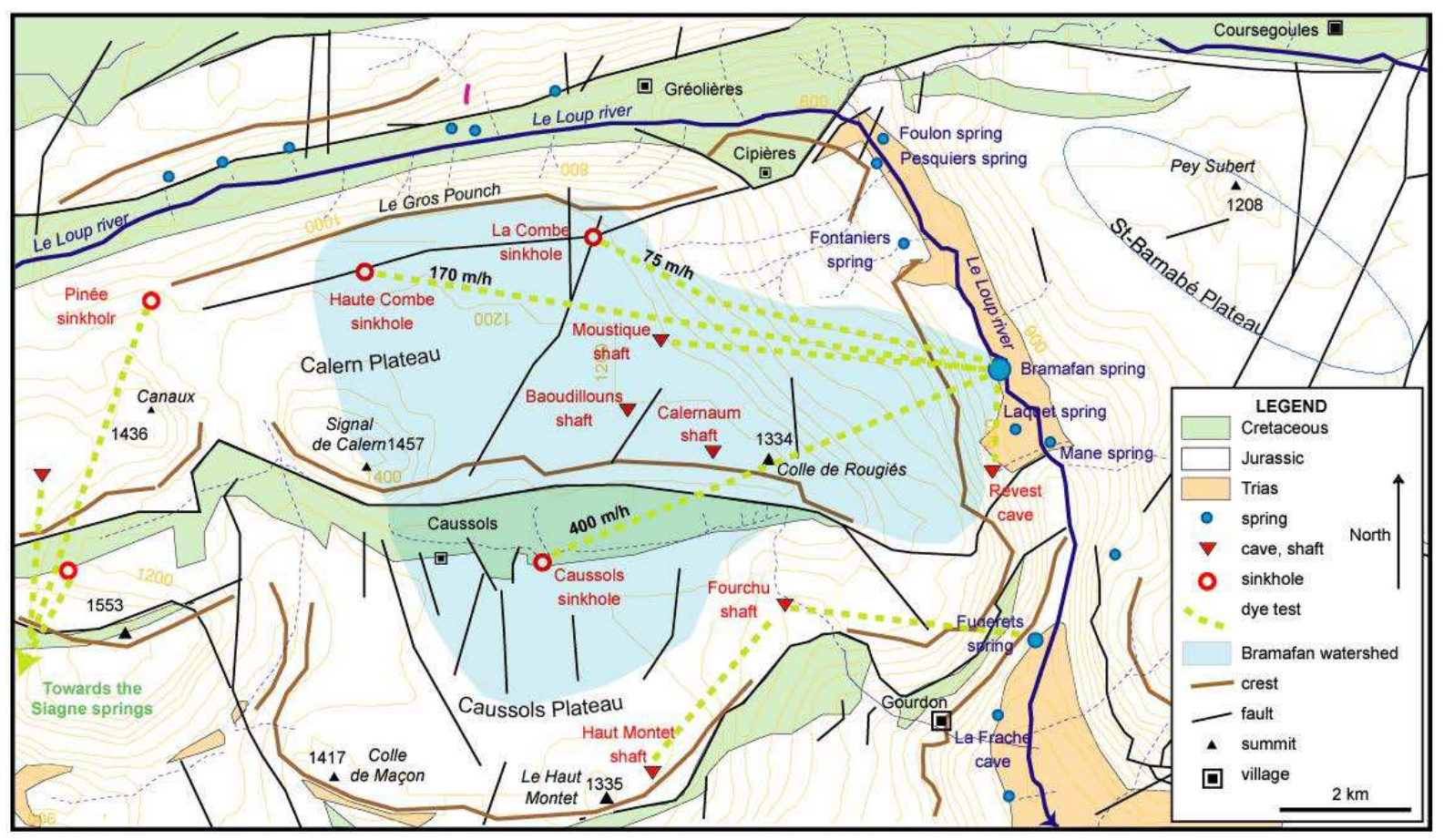

Figure 11 : Watershed of Bramafan spring deduced from the dye test of 2008

\section{METHODOLOGY TO COMPARE TILT AND HYDROLOGICAL SIGNALS}

\subsection{Hydrology}

With the lack of discharge monitoring for the different springs, we adopted a correlationbased approach to link the hydrological state of the aquifer, with changes in physical water parameters (temperature, conductivity, pressure). We consider that winter-time rain temperature is lower than karst water while in summer it is higher. Water mineralization is also measured at the outlet by electrical conductivity. Rain water is poorly mineralized whilst water in contact with the limestone during several weeks dissolves $\mathrm{CaCO}_{3}$. Figure 12 shows an example of correlation.

- In winter dry period the infiltrated rainwater warms up and its mineralization gradually increases.

- In summer dry period infiltrated rainwater cools down and its mineralization gradually increases too.

- In winter rainy period, abundant rainfall flushes away the older saturated water contained in cracks and small drains, which results in a short increase in temperature and conductivity. Then poorly mineralized cold water reaches the outlet, which induces a sharp decrease in temperature and conductivity. A few days after the rainy period, water temperature and mineralization gradually comes back to its mean values.

- During summer storms, hot rainwater with low mineralization reaches the outlet, a general temperature increase and a sharp mineralization decrease may be observed. 
This behavior is usually more complex and is related to the difference of temperature between rain and aquifer water, the length of dry periods, and the damping behavior of the aquifer structure.

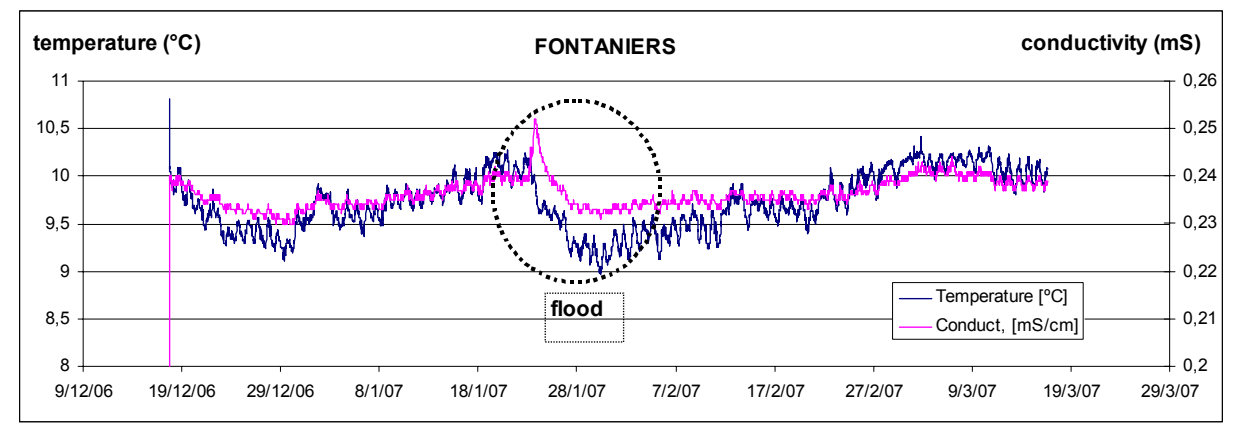

Figure 12: Example of response of a spring to a rain event.

Different sites were instrumented with CTD probes since late 2006 (Table 1). Revest and Bramafan sites have been considered as representative to interpret tilt observations, the other sites have been abandoned following initial results. CTD data covers two complete hydrological years, from July 2007 to the end of May 2009

\begin{tabular}{|c|c|c|c|c|}
\hline Site & Duration & Type & $\begin{array}{l}\text { Connection to } \\
\text { rainfall }\end{array}$ & Connection to tilt \\
\hline Bramafan & 18/07/07_08/06/09 & Deep karst aquifer & quick & good \\
\hline Revest & 16/03/07_06/06/09 & Deep karst aquifer & quick & good \\
\hline Moustique & 16/03/07_29/06/09 & Deep karst aquifer & quick & poor \\
\hline Caussols & 16/03/07_06/04/08 & Epikarst & quick & poor \\
\hline Fontaniers & 16/03/07_06/04/08 & Slope aquifer & damped & poor \\
\hline Castel Bon Pré & 16/03/07_06/04/08 & Slope aquifer & damped & poor \\
\hline
\end{tabular}

Table 1 : List of instrumented sites

\subsection{Tiltmeters}

Two long baseline tiltmeters were installed, at a depth between 30 and $40 \mathrm{~m}$, in the shaft of Cipiernäum, located in the Calern plateau, close to OCA observatory. They have been operating continuously since July 2007. Two tiltmeters are required to determine the inclination of a plane, which allow the reconstruction of NS and EW tilt vectors.

The first tiltmeter is 9 meter long and oriented towards $\mathrm{N} 05^{\circ} \mathrm{E}$, close to the NS direction. The second one is 5 meter long and oriented towards $\mathrm{N} 140^{\circ} \mathrm{E}$ direction, closer to the $\mathrm{EW}$ direction. Instruments are powered by solar panels, buffer batteries being located in a chamber $10 \mathrm{~m}$ below ground accessible by a fixed ladder. A narrow $15-\mathrm{m}$ long passage leads to the data loggers. Finally, another $15-\mathrm{m}$ height ladder leads to the first tiltmeter. The second tiltmeter is $10 \mathrm{~m}$ below (Fig 13). 


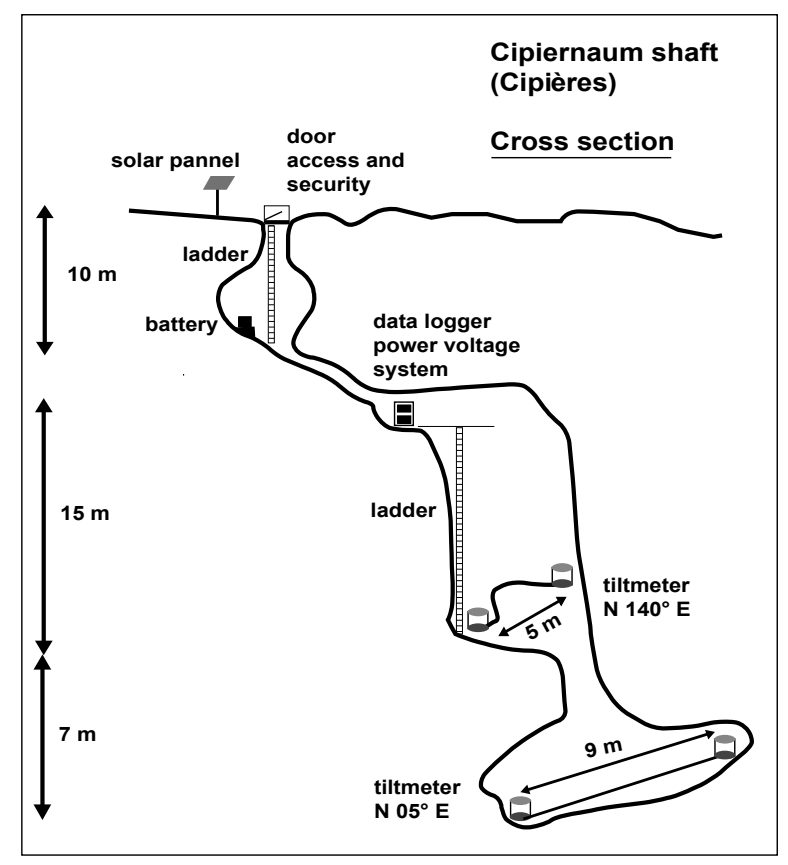

Figure 13. Simplified diagram of the Cipiernaum shaft and the tiltmeters settlements.

The tiltmeters measure the angle $\Omega$ between the geoid (or equipotential surface) and the base of the instrument (Fig 14). For nearby loadings, the variation of the geoid can be considered negligible [11].

The measurement principle of a long base hydrostatic tiltmeter is simple, based on hydrostatic leveling. Two vessels linked by a pipe and filled with liquid. A tilt deformation induces liquid transfer from one pot to the other pot, and therefore liquid height variations, positive in a pot and negative in the other one. Water level variations are measured by floats attached to a Linear Variable Differential Transformer (LVDT) displacement sensor. The base length of the instrument, i.e. the distance between the vessels may range from a few meters to several hundreds of meters.

The sensitivity of the instrument in terms of angle is very high, expressed in $\mu \mathrm{rad}=10^{-6} \mathrm{rad}$. One $\mu \mathrm{rad}$ is equivalent to a vertical deformation of $1 \mathrm{~mm}$ on a base of $1 \mathrm{~km}$. A more detailed description of the tiltmeters can be found in Boudin et al. [12].

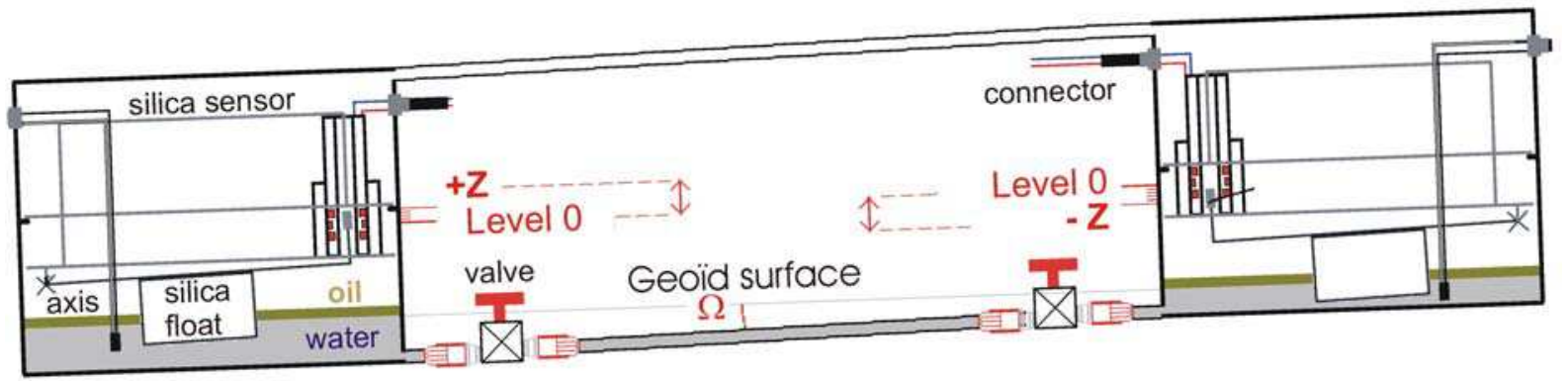

Figure 14 : Schematic diagram of the long base silica tiltmeter presented in this paper. It is a full-filled horizontal water tube whose crucial components are made in silica to minimize the temperature effects. The $\mathrm{T}$ connections, between the vessel and the tube, allow easy interventions or partial replacements. $\tan \Omega=\frac{2 \mathrm{z}}{\mathrm{L}} \cong \Omega$ with $\Omega$ angle $; \mathrm{z}+$ and $\mathrm{z}$ - variation of liquid level in each pot $; \mathrm{L}$ length of the system, 


\section{HYDROLOGICAL DATA}

The quality of collected data allow to characterize the different hydrological systems. Observed data for different aquifers is shown in Figure 15:

- slope aquifers with reduced fluctuations (Fontanier, Castel Bon Pré),

- epikarstic aquifer with important fluctuations (Caussols sinkhole),

- deep karst aquifers with important fluctuations of the water table (Bramafan, Revest, Moustique),

Strong and sudden rises of the water table level in the deep karst aquifers may be observed, directly linked to rainfall events. They are as large as $100 \mathrm{~m}$ in the Revest cave (Fig 15), as observed in the past by Audra [13].

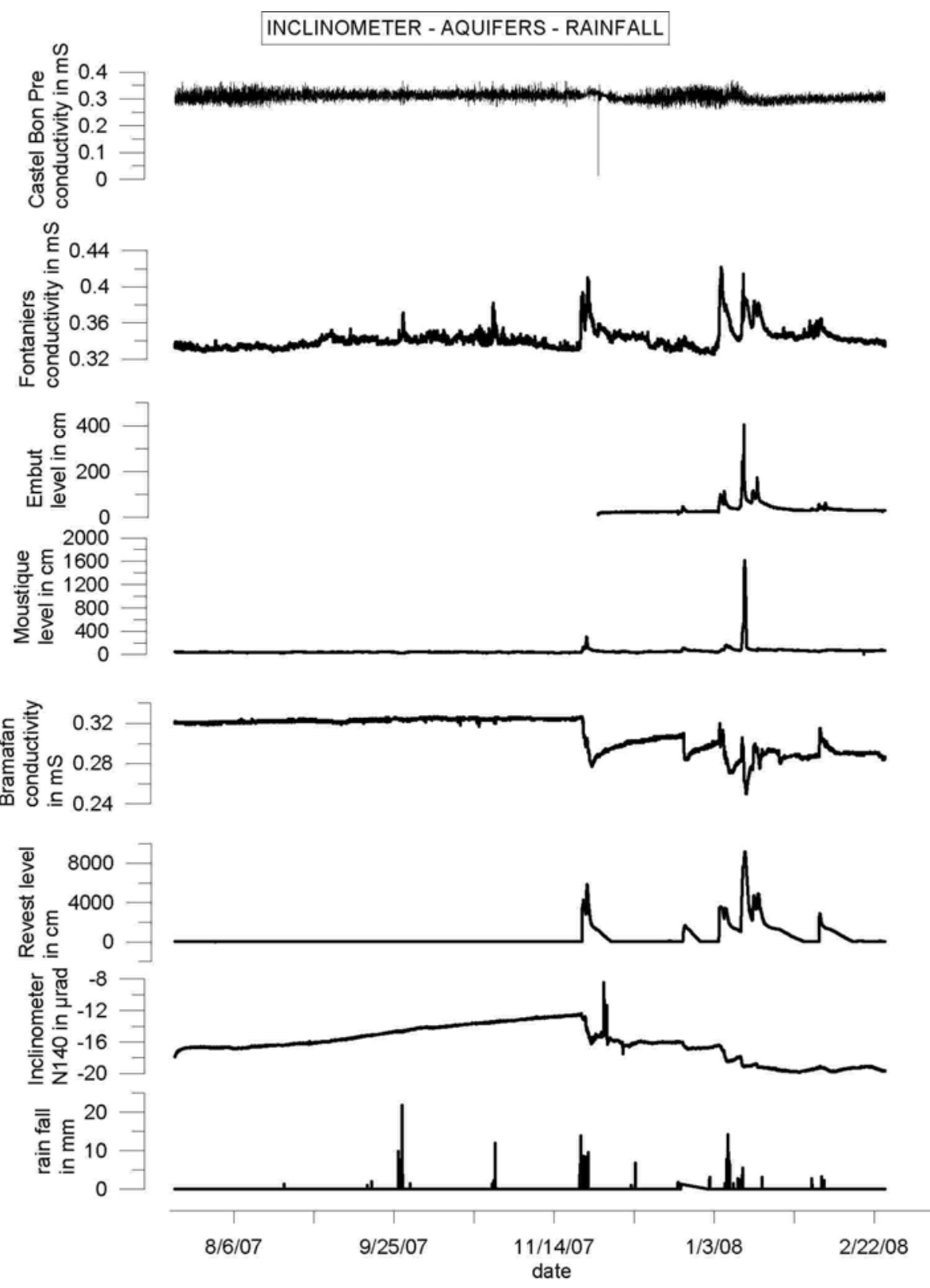

Figure 15 : Hydrological and tilt data correlated with rainfall in Calern. 


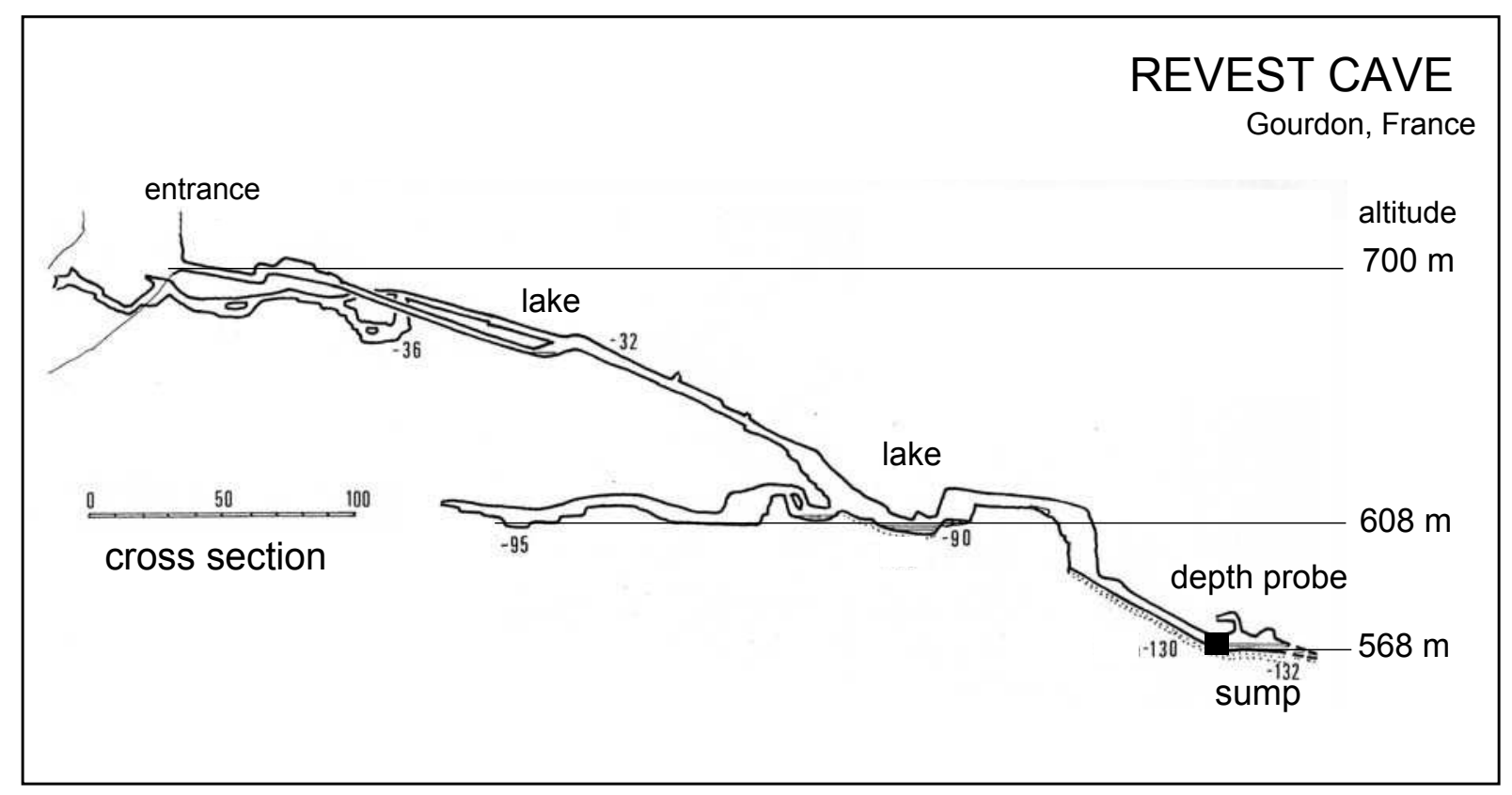

Figure 16: Cross section of the Revest cave.

\section{TILT DATA}

\subsection{Collected data}

Both instruments have been monitoring since July 2007 without interruption. Their resolution is close to $10^{-8}$ rad as indicated by their capacity to observe Earth tides. They have also recorded the Sumatra earthquake $\mathrm{M}=8.2$ on 12/09/2007 ( Fig 18).

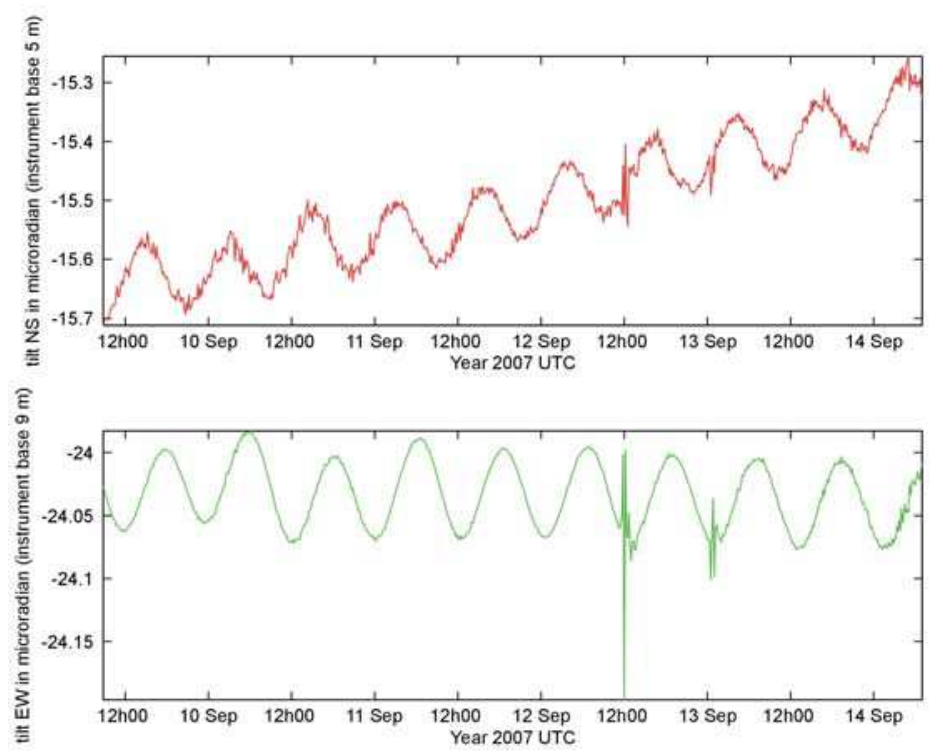

Figure 17 : Observation of earth tides with a period close to 12 main 24 min.

Tilt variations associated with large rainfall events may be observed on both instruments, on both directions. Several events may be highlighted, such as November 2008 or January 2009 events (marked as 1 and 2 in Fig 18 ), but also early November 2009 or late December 2009 events (marked 4 and 5 in Fig 18) or in spring (marked 3 and 6, in Fig 18). 


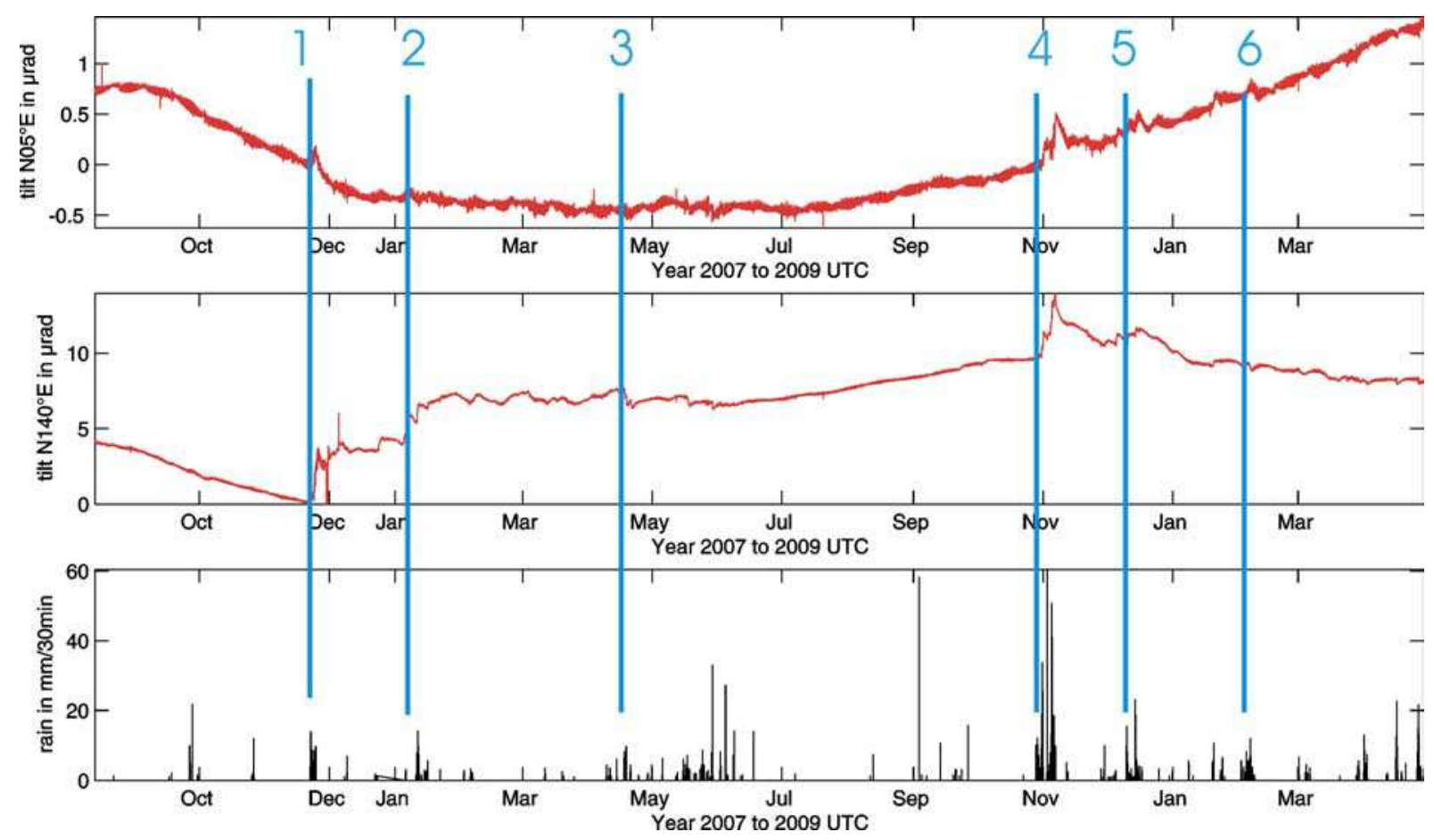

Figure 18: Tilt data from July 2007 to May 2009, in the respective directions $\mathrm{N} 05^{\circ} \mathrm{E}$ and $\mathrm{N} 140^{\circ} \mathrm{E}$. (Nota : Earth tides are not compensated for the $\mathrm{N} 05^{\circ} \mathrm{C}$ tiltmeter)

\subsection{Weather-related variations}

We have measured the temperature inside the shaft of Cipiernaum, (Fig 19 B), in parallel with the tilt recordings (Fig $20 \mathrm{~A}$ ). We also have measured the air pressure on the Calern plateau, (Fig 19 C). Temperature variations are observed over the hours and days following heavy rainfall, they are, however, not correlated with the corresponding positive tilt variations. In particular, there is negative variation in temperature during the months of March and April 2009, when snow is melting, but we did not notice negative tilt variations.

The recording of pressure changes showed no correlation with the recording tilt. In particular, the highest pressure variation seen beginning in March 2009 is not associated with corresponding tilt variation. Atmospheric pressure variations have been shown to induce tilt deformation, however, their amplitude is generally reduced to $0.03 \mu \mathrm{rad}$ [14] and will be considered as negligible, Thus we consider that our measurements are not subject to adverse disturbances for the ongoing project. 


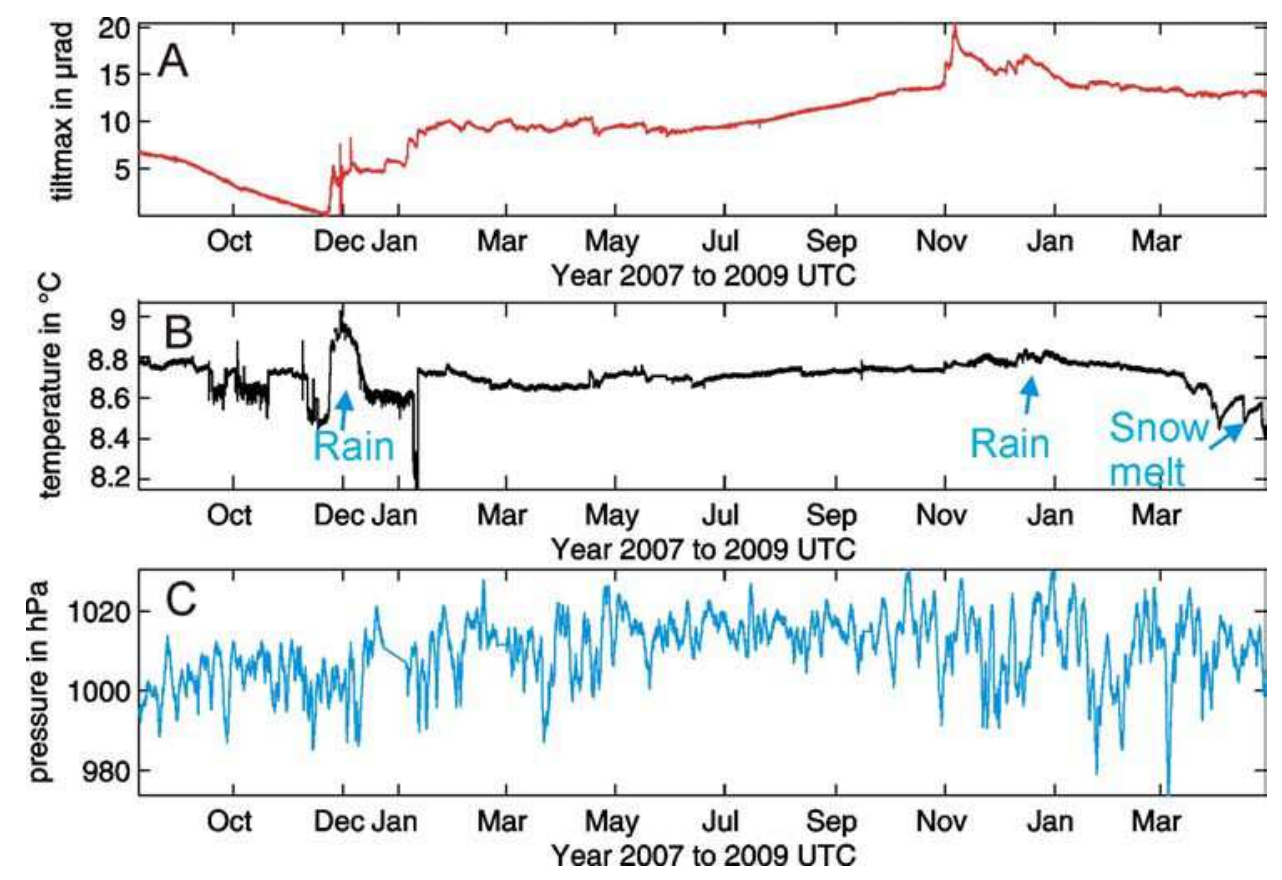

Figure 19 : Tilt compared with weather data. A / maximum tilt variations. B / Variation of temperature in the shaft of Cipiernaum. C / Pressure change on the Calern plateau.

Tilt variations from both instrument and accumulated rainfall may now be compared (Fig 20 $A \& B$ ). There is a strong correlation between the 2 observations. For short-term variations, each rainfall event is associated with a tilt variation. This contribution is not reduced to a few days to several weeks, longer term contribution over several month and probably several years are probable.

Short-term azimuth and maximum deformation are provided on figure $20 \mathrm{C}$. Rainy periods are associated with a definite direction, $\mathrm{N} 100^{\circ} \mathrm{E}$; whereas dry periods are associated with $\mathrm{N} 90^{\circ} \mathrm{E}$ direction
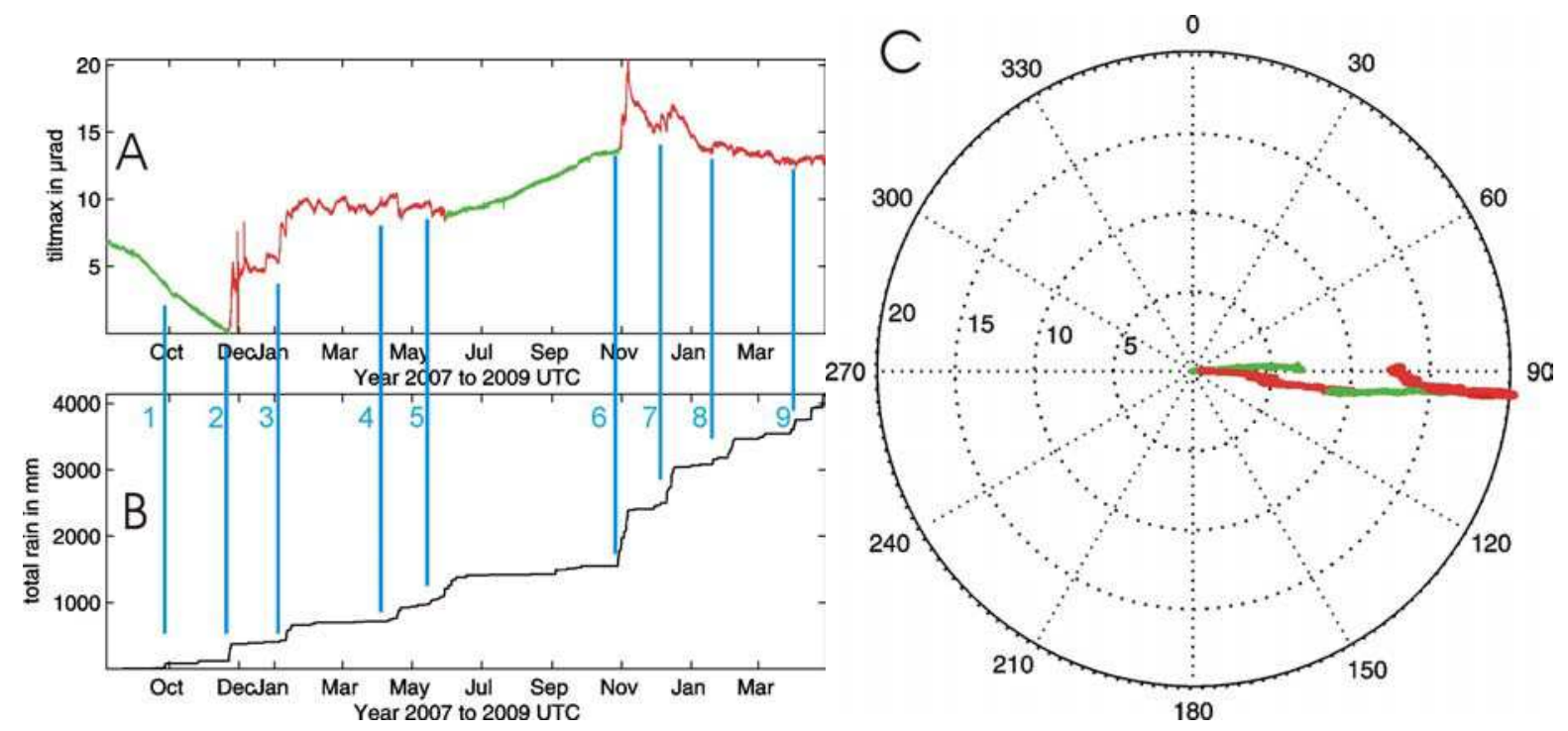

Figure 20: Tilt and rainfall data. A / maximum tilt gradient obtained from the two N05 ${ }^{\circ} \mathrm{E}$ and $\mathrm{N} 140^{\circ} \mathrm{E}$ tilt components (in $\mu \mathrm{rad}$ ). B / Accumulated rainfall on the Calern plateau (in mm). C / corresponding azimuth (in ${ }^{\circ}$ ). 


\subsection{Relation with the hydrogeology}

- Relation tilts / slope aquifers (Caussols, Fontanier, Castel Bon Pré)

No relationship appears between the fluctuations of groundwater and the tilt.

- Relation: tilts / deep aquifers (Bramafan, Revest, Moustique)

A very good correlation is observed between water table variations observed at the Bramafan spring and the Revest cave. It may be noted that the spring of Bramafan is roughly localized $\mathrm{N} 90^{\circ} \mathrm{E}$ from the tiltmeters of Cipiernaum, thus in the direction of the maximum loading (Fig 21).

The Perched aquifer of Moustique shaft appears to be disconnected from the deep aquifer of Bramafan and no impact on the tilts was observed. This area responds only during heavy rains.

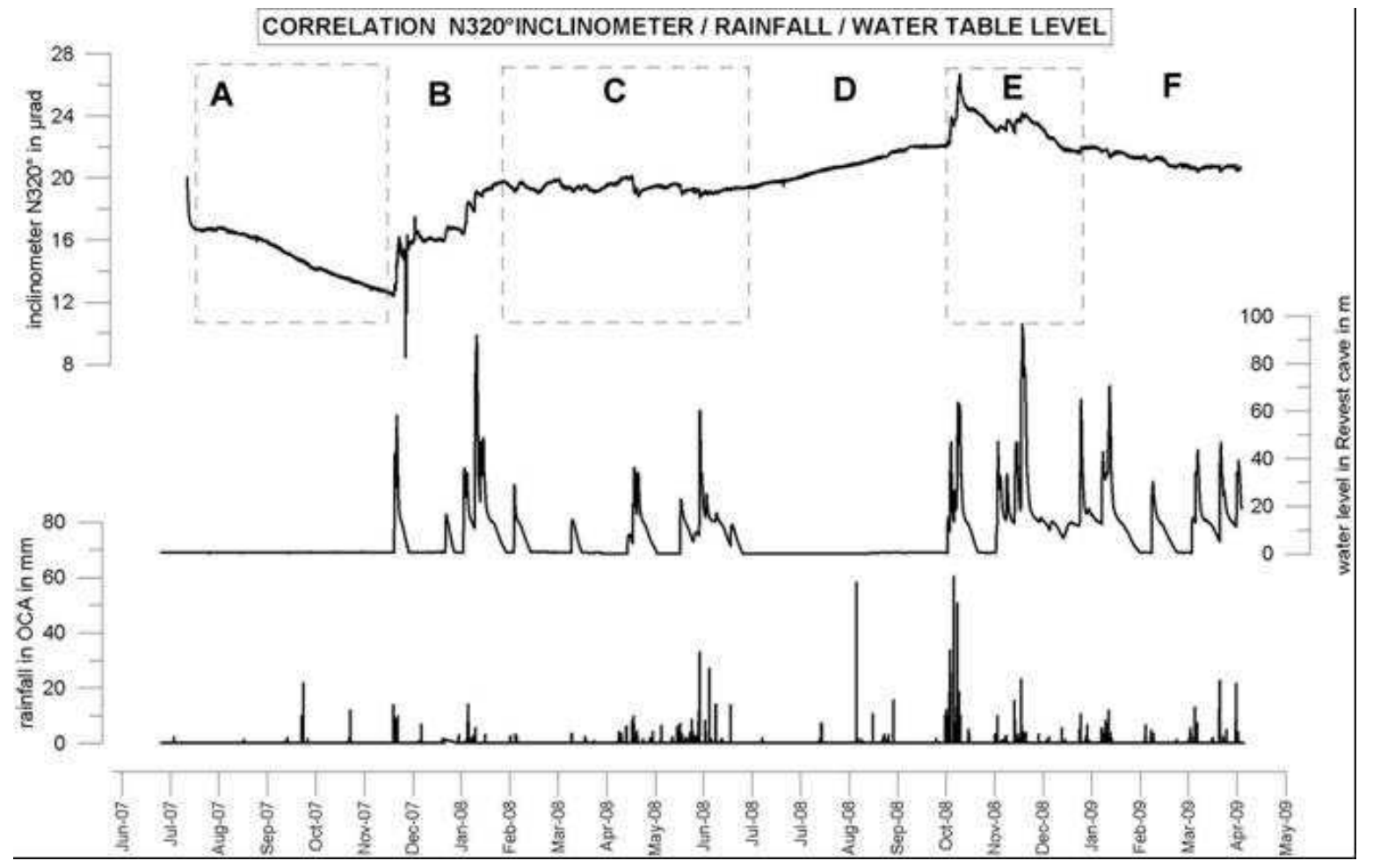

Figure 21 : N140 ${ }^{\circ}$ Tilt variations : relationship with rainfall in Calern and water table level fluctuations in the Revest Cave.

\section{ANALYSIS OF THE VARIATIONS}

\subsection{Global variations}

Six stages may be highlighted to the behavior of the tilt deformation (Fig 21) :

A / During the summer 2007, the plateau tilts up, September and October 2007 rainfall in Calern have no effect on the water level in the Revest-Bramafan aquifer.

B / Rainfall induces important rising up of the water level in the aquifer, and there is a very good correlation with the tilting, from November 2007 to January 2008 
C / From January 2008 to June 2008, rainfall go on inducing an important rising up of the water level in the aquifer but the plateau stops to tilt. There are slight tilting reaction to rainfall.

D / During the summer 2008, rainfall has no visible effect neither on the aquifer nor on the plateau, but this one slightly tilts down.

$\mathrm{E} /$ this stage is similar to B as rainfall causes the plateau to tilt

$\mathrm{F} /$ this stage is similar to $\mathrm{C}$ as the plateau stops tilting

Thus, each major winter rainfall event is associated with a $\mathrm{N} 100^{\circ} \mathrm{E}$ loading measured by the tiltmeters. Meanwhile A and D are not influenced by the rainfall and the direction of the movement is opposite. To study this peculiar behavior a more precise analysis was done. Data was filtered to study long term and short term tilting variations, splitting the signal in its components at longer and shorter periods than 66 days (data is decimated to daily time step, then high pass and low pass filters are applied).

\subsection{Short term variations}

The short term variations (Fig 22) are well correlated with the rainfall and the reaction is immediate. Meanwhile two different reactions may be highlighted: a positive reaction (P1) where tilt increases and a negative one (P2) where tilt decreases. This does mean that at least, two mechanical deformation processes are involved, and not necessarily linear with rainfall amount. Both P1 and P2 depend on the rainfall but they may add, subtract or compensate. We assume that two different reservoirs are playing a role, a surface one (epikarst) and a deep one (Bramafan deep aquifer). The tiltmeter series vary accordingly to the amount of water accumulated in each reservoir. The deeper reservoir is only filled when the surface one is saturated.

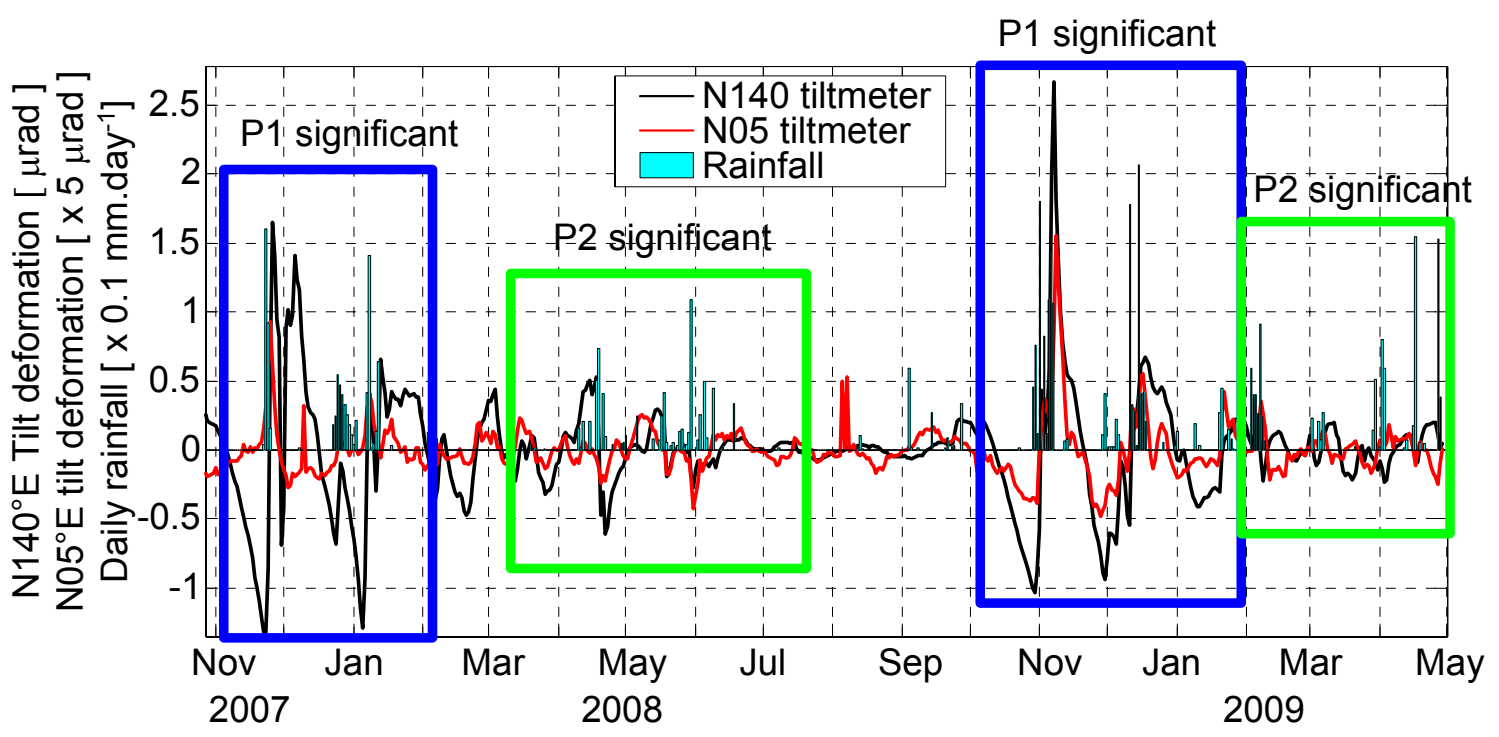

Figure 22 : Short term tilt variations and their relation to rainfall events.

\subsection{Long term variations}

The long term variations (Fig 23) provide similar indications when interpreting $\mathrm{N} 140^{\circ} \mathrm{E}$ tiltmeter data. During the first part, the shallow and deep reservoirs are empty. When the first 
rains arrive, the process P1 masks P2 - the deep reservoir is empty. In April 2008, the epikarst is saturated and rainfall flushes the water towards the deep aquifer, P1 and P2 are compensated. In July 2008, raining stops, P2 masks P1 because most of the water migrates from the epikarst to the deep aquifer. In November 2008, the rains arrive and the process starts over. In January 2009, the epikarst is saturated, water is pushed down. It continues to rain, but all the water deeply infiltrates and P2 masks P1. Interpretation of long-term variations of $\mathrm{N}^{\circ} 5^{\circ} \mathrm{E}$ tiltmeter is not straightforward, and long time series would be required.

An attempt with two hydrological models made it possible to retrieve time constants in the behavior of tilt series, but the final quantification is difficult, as the deformation process are unknown. More accurate data on Bramafan spring discharge, and longer series are required to better set up hydrological models.

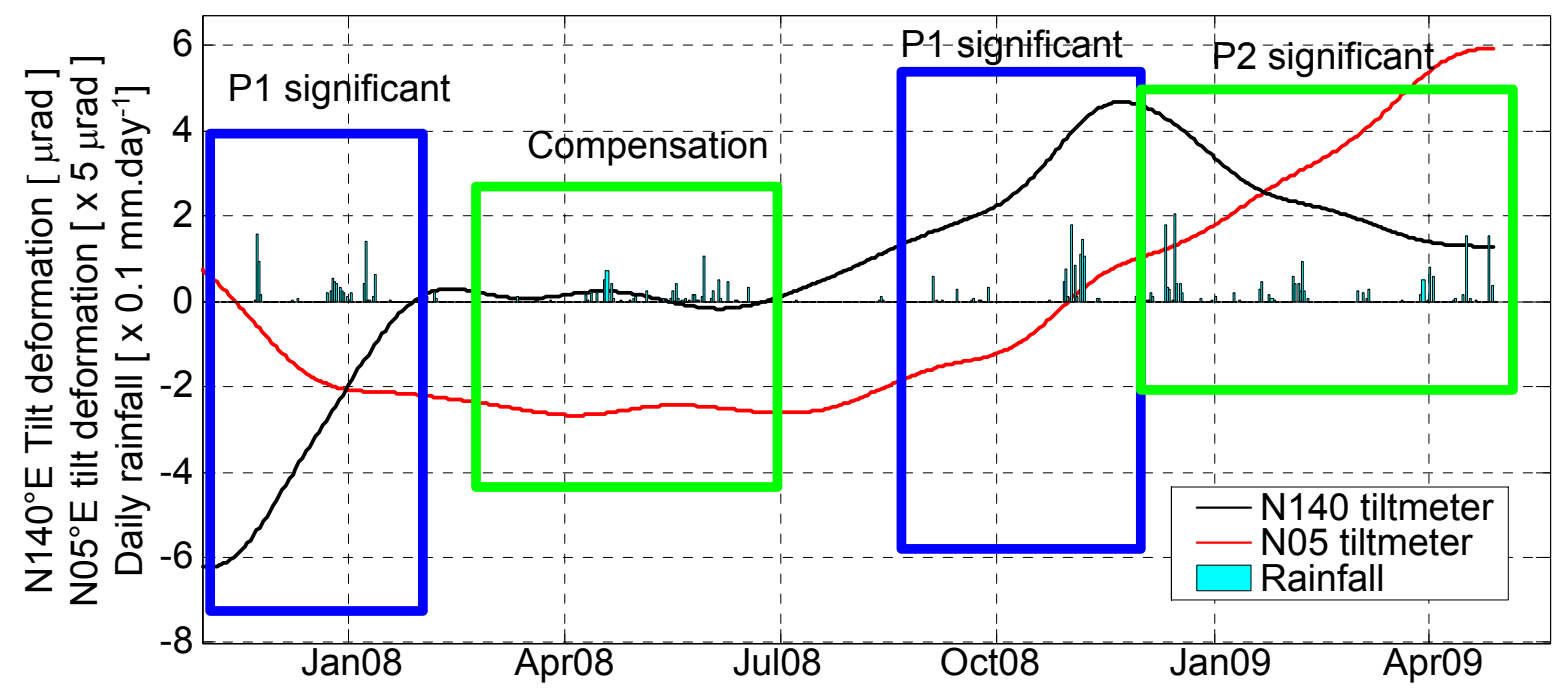

Figure 23 : Long term tilt variations

\section{SUMMARY OF RESULTS}

\subsection{Principle and mechanism}

At least two mechanisms are involved to explain the tilt variations: a surface mechanism and a deep mechanism. We also have to take into account a specificity of the karstic system. Indeed

the observation of the Bramafan recession curves shows a rupture that corresponds to a water table level of $593 \mathrm{~m}$ (Fig 24). Below this altitude, the drainage of the system is accelerating which reflects, either the end of the emptying of an aquifer compartment, or a reduced geometry for the deep parts of the aquifer. 


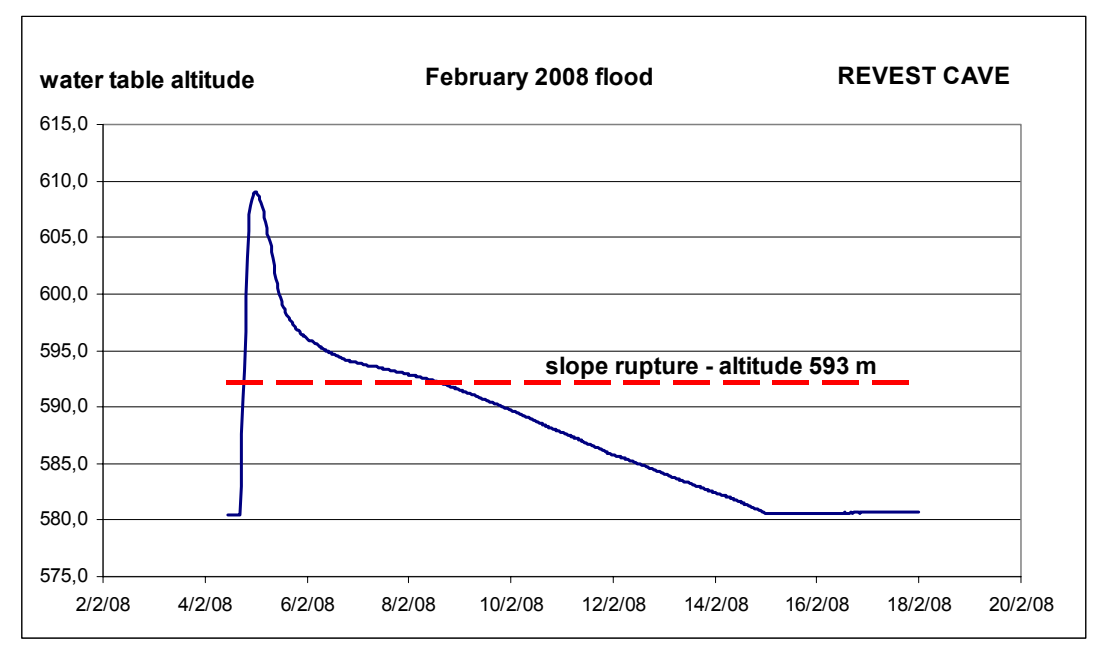

Figure 24 : Variation of the slope of the recession curves recorded in the Revest cave.

This observation and the geological context leads us to propose a model in which the epikarst and the deep karst aquifers are both involved in the tilt variations. The mechanical processes associated with water quantity in epikarst and deep karst aquifers add, compensate or subtract. The deep aquifer is contained in a restricted area and has a main low outlet (Bramafan) but also higher ones (there are several springs between Bramafan and Revest) that activate during high water periods. During the floods the water level may rise up to these outlets. Figure 25 attempts to outline the dynamics of the aquifer.

Phase A : the long-term tilt variations at the beginning of the measures is linked with the progression of low flow at the end of a drought. In autumn, the first rains recharge the epikarstic aquifer and replenish its reserves that have gradually declined during the progression of low flow.

Phase B : the winter rains flush down the water and induce a rapid transit towards the deep aquifer. Punctual variations are then measured by the $\mathrm{N} 140^{\circ}$ tiltmeter. Each one is correlated with rainfall and water table rising in the deep karst aquifer of Bramafan-Revest. The epikarst is saturated and the deep reserves are recharged. The rising up of the water table is limited by the high outlets of the system (altitude $700 \mathrm{~m}$ ).

Phase C: The system is then balanced but may be slightly disrupted during heavy rains when the discharge of the higher outlets is not sufficient to evacuate the whole water.

Phase D : The summer period is not dry enough to evacuate all the water and to induces a reverse tilting like in 2007.

Phases E and F : these periods are similar to B and C but as 2008 is a normal period and both epikarst and deep karst participate to the tilting. 


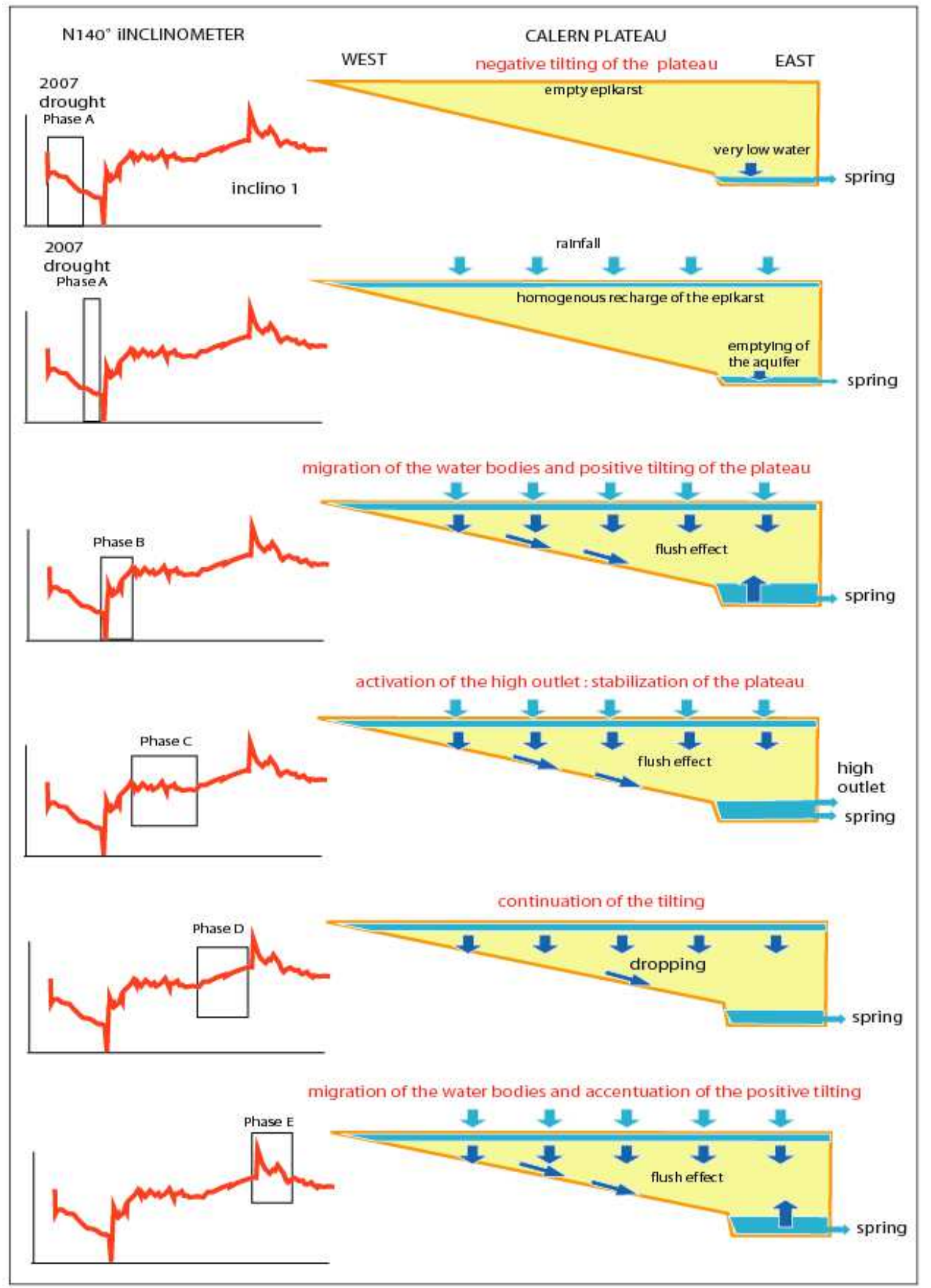

Figure 25 : Conceptual scheme of hydrological changes and their consequences on geodesy. 


\subsection{Elementary quantitative modeling of the deformation}

A simple model to simulate the system can rely on the response of an homogeneous environment to a point load, ignoring the change in the geoid. According to the principle of Boussinesq [15] the flexure due to a punctual loading is :

Tilt $(d P(r), r)=\frac{\lambda+2 \mu}{\lambda+\mu} \times \frac{d P(r)}{4 \pi \mu r^{2}}$

where $\lambda$ and $\mu$ are the elastic parameters of the limestone. For those rocks, typically, $\lambda$ ranges within $1.710^{-10} \mathrm{Nm}^{-2}$ and $4.310^{-10} \mathrm{Nm}^{-2}$ while $\mu$ lies between $2.110^{-10} \mathrm{Nm}^{-2}$ to $3.010^{-10}$ $\mathrm{Nm}^{-2}$.

We can then model the tilt effects by convoluting this Green function with a given water loading, taking into account the direction of the maximum tilting between 90 and $100^{\circ} \mathrm{E}$. We chose an area of $4 \mathrm{~km} \times 2 \mathrm{~km}$, located between the tiltmeter and the Bramafan spring. It then includes the effect of the amount of water that can be found in the deep aquifer of Bramafan following rainfall, a water volume of 25 million $\mathrm{m} 3$, and it is assumed that the whole water accumulates below this surface.

For the tilt station, the computation leads to a signal of $4 \mu \mathrm{rad}$, which is the same order of magnitude as the short term variations.

\section{Conclusion}

This study establishes that the deformations induced in a karst system by the weight of water bodies is significant and measurable. A good correlation is observed between the rainfall and the tilt variations. This could be an interesting method to evaluate the size of the water bodies but the observed signal remains difficult to analyze. Two main reasons are invoked, the signal has probably two components : a surface one and a deep one. They are correlated to water but the mechanical effect is still unknown. A possible explanation is a differential repartition of the water bodies, from dry water to high water seasons.

Can we go further ? As it stands, it is difficult because we need information on the spatial distribution of water in the karst system, related to time. We also need to know more about the detailed distribution of elastic parameters of fractures and voids in the karstic massif. A further approach by using finite-element modelling would also be necessary, as in Kroner et al. [16].

\section{References}

[1] Walch J.J., Gravimétrie absolue et géodynamique sur le plateau de Calern. Proceed . Riviera 2000 Conf. "Tectonique active et géomorphologie ». Rev. Analy. Spat. $\mathrm{N}^{\circ}$ spéc. University of Nice, (2001), 155-159

[2] Nicolas J., Nocquet J.-M., Van Camp M. and Walch J.-J, 2003, Laser, GPS and Absolute Gravimetry vertical positioning time series comparison at the OCA observatory, France , Eos Trans. AGU, 84(46), Fall Meet. Suppl., (2003) 
[3] Laclare, F. \& Cormier, P. Measurements of the Stability of the Pillars by Clinometry at CERGA. Astronomy and Astrophysics. Supp. Ser. V. 43, (1981) 247-250

[4] Audra, Ph. 1998, Mise en charge exceptionnelle dans le gouffre de Calernaum (Alpes Maritimes). Origine et conséquences du phénomène sur l'organisation des circulations profondes. Et. Géogr. Phys. 27, (1998), 93-100

[5] Gilli E., Recherche de causes potentielles de variations gravimétriques dans l'endokarst du plateau de Calern. Actes Coll. Agret 2000, Grasse 8-10 nov 2000. CNRS INSU (2002)

[6] Nicolas J., Nocquet J.-M., Van Camp M., Boy J. P., Hinderer J., Amalvict M., Gegout P., Calais E. and Walch J.J., Seasonal effects on Laser, GPS and Absolute Gravimetry vertical positioning at the OCA-CERGA geodetic station, Grasse (FRANCE) $14^{\text {th }}$ international workshop on laser ranging, NASA, San Fernando, June $7-11^{\text {th }},(2004)$

[7] Gilli E., Néotectonique dans les massifs karstiques. Un exemple dans les Préalpes de Nice: la grotte des Deux Gourdes. FFS, AFK, Karstologia 8 (1986), 50-52

[8] Gilli E., Recording of earth movements in karst . 5th Int. Conf. Seism. Zonation. oct. 17$19^{\text {th }} 1995$, Nice, AFPS. EERI. Ouest Edit., Nantes, (1995), 1305-1314

[9] Gilli E. , Delange P., Recent, slow and aseismic movement of an overthrust observed in the Abel sink hole (St Vallier de Thiey, 06, France). Proceedings coll. Han 98, in Geodinamica Acta, 12. 3-4, (1999), 169-178

[10] Calais, E., R. Bayer, J. Ch'ery, F. Cotton, M. Flouzat, F. Jouanne, J. Martinod, F. Mathieu,O. Scotti, M. Tardy, C. Vigny, REGAL: A permanent GPS network in the French Western Alps, Configuration and first results, C.R. Acad. Sci. Paris, 331, (2000), 435-442,

[11] Florsch, N., Llubes, M. Wöppelmann G., Longuevergne, L., an Boy, J.P.,. Oceanic loading monitored by ground-based tiltmeters at Cherbourg (France). Journal of Geodynamics, in press, (2009)

[12] Boudin, F., Bernard, P., Longueverg,e, L., and Florsch, N.,. A silica long base tiltmeter with high stability and resolution. Rev. Sci. Instrum. 79, (2008); DOI:10.1063/1.2829989

[13] Audra $\mathrm{Ph}, 2007$, Karst et spéléogenèse épigènes, hypogènes, recherches appliquées et valorisation. These HDR géographie, Université de Nice, 457 p.

[14] Boy, J.-P., L. Longuevergne, F. Boudin, T. Jacob, F. Lyard, M. Llubes, N. Florsch and M.F. Esnoult, Modelling atmospheric and induced non-tidal oceanic loading contributions to surface gravity and tilt measurements. J. Geodyn. (2009), doi:10.1016/j.jog.2009.09.022

[15] Boussinesq, J., Application des potentiels à l'étude de l'équilibre et du mouvement des solides élastiques, Gauthier-Villars, Paris, 1885.

[16] Kroner, C., Jahr, T., Kuhlmann, S., \& Fisher, K.,. Pressure-induced noise on horizontal seismometer strainmeter records evaluated by finite element modelling, Geophys. J. Int. 161, (2005), 167-178 